\title{
How Important is Twitter to Local Elections in Brazil? A Case Study of Fortaleza City Council*
}

\author{
Francisco Paulo Jamill Marques \\ Universidade Federal do Paraná, Brazil \\ Camila Mont'Alverne \\ Universidade Federal do Paraná, Brazil
}

\begin{abstract}
Studies on the effects of the internet on elections have revealed how Social Network Sites (SNSs) are used by citizens to learn about, choose and contact their representatives. This article analyzes 27 Twitter accounts managed by Fortaleza's city councilors who ran for reelection in October 2012. The study aimed to discover the importance of Twitter in the councilors' campaign strategies: what kind of messages were sent by the councilors who adopted digital communication strategies to their followers, and the relationship between party affiliation and e-campaigns. The article shows that communitarian sociability, understood as face-to-face relations or interactions among individuals, affects how the internet is used in local campaigns, since there is no direct relationship between electoral success and the heavy use of Twitter by candidates, at least in proportional local elections (which are defined as cases in which candidates do not necessarily need to reach the votes of a majority of constituents, but only a part of them). However, those who adopt a digital communication strategy use it to broadcast their political platforms and promote their campaign events. Finally, except for small left-wing parties, there appears to be no relationship between party affiliation and e-campaigns.
\end{abstract}

Keywords: Internet; social network sites; elections; political campaigns; local power. 
W hile investigating the motivations that lead citizens to choose their candidates, different studies in political science and electoral behavior emphasize the importance of acknowledging multiple factors that can influence voting decision: the transitory economic and political conditions; the degree of knowledge that voters have about candidates; which political coalitions the candidates belong to; whether the candidates have the support of local, state and national authorities; the plurality of the journalistic coverage, with its frames and emphases; the contents that characterize electoral advertising; the performance of competitors in public debates; and the results of opinion polls (BAQUERO, 1997; BORBA, 2005; CARREIRÃO, 2000; CASTRO, 1997; CHAIA et al., 2002; FIGUEIREDO, 1991; POPKIN, 1994; PRZEWORSKI et al., 2003; TELLES et al., 2009).

A significant part of these topics are tied to the mass media, as most information and images about politics available to constituents are provided by mass communication channels (GAMSON, 1992; GOMES, 2004; HACKER, 2004; MIGUEL, 2000; SCHUDSON, 1995; SELLERS, 2010; SKIDMORE, 1993; SWANSON and MANCINI, 1996). More recently, the internet has brought important changes to political campaigns (ALDÉ and MARQUES, 2015; ENLI and SKOGERBO, 2013; HOWARD, 2005; KARLSEN, 2010), wherein candidates adopt digital media as a political campaign strategy to introduce a different interactive scenario in which citizens could enjoy the opportunity of having access to multiple sources of information, questioning candidates in a public arena and creating independent projects that demand answers from parties and coalitions (BIMBER and DAVIS, 2003; BRAGA et al., 2013; COLEMAN, 2001; HOWARD, 2006; MAIA, 2011; MILLIKEN, 2011; MARQUES et al., 2013; MENDONÇA and PEREIRA, 2012).

A balance of the main works that have studied e-campaigns over the last few years allows us to identify two phenomena that still need to be investigated. First, there is a permanent tension between (a) projects aimed to increase democracy's practices and (b) initiatives related to a strategic use of digital media. Therefore, the internet can be a dubious tool for political agents, since they cannot completely control the messages sent to or posted by users on the candidates' social network sites, or SNSs (JACKSON and LILLEKER, 2009; STROMER-GALLEY, 2000). Second, digital communication has led users to expect more from politicians (at least regarding political communication strategies). Now, candidates or representatives need to utilize multiple SNSs if they aim to show

(2016) $10(3)$


constituents how "interactive" they are, even if online conversations do not influence candidates' platforms or real-life actions. Therefore, a greater sense of competition between candidates can stimulate an increased use of digital media (DRUCKMAN et al., 2009; MARQUES et al., 2011; WILLIAMS and GULATI, 2010).

Our aim is to highlight this unprecedented window of opportunity for candidates to influence voters. Through digital media, candidates "can reach large numbers of constituents for a relatively small fixed cost" (GLASSMAN et al., 2010, p. 2). Through this research, we seek to contribute to the existing literature by examining 27 Twitter accounts managed by Fortaleza's city councilors who ran for reelection in October 2012, to analyze how the internet has been used to reach voters. The objective is to understand if and how local sociability, understood as relations and interactions among individuals, influences how digital communication is used by candidates who are running a reelection campaign.

Notwithstanding the fact that many scholars in social and human sciences interpret the notion of sociability differently, the term has been commonly referred to social interaction in groups (PREECE, 2000). In other words, sociability can be understood as "the ensemble of intercurrent relations or interactions among the individuals who are part of a given society" (FORTUNATI et al., 2013, p. 895). Studies dedicated to explore the relationship between sociability and digital media stand that the internet has weakened social ties (PUTNAM, 2000), while others believe it has reinforced social ties (WELLMAN et al., 2001). According to Papacharissi (2012):

So-called social media enhance a particular type of sociability networked sociability. [...] Networked and remixed sociabilities emerge and are practiced over multiplied place and audiences, that do not necessarily collapse one's sense of place, but afford sense of place reflexively. [...] The ability for individuals to efficiently avail themselves of the potential of social network sites depends on the individual level of access, literacy, and general comfort with socially networked platforms of interaction. Adept navigation of the social landscapes of SNSs implies that identity is performed, but is also edited across multiplied and converged audiences." (PAPACHARISSI, 2012, pp. 217-218).

This study examines a proportional local election and argues that, in such contexts, communitarian sociability implies a weak connection between electoral success and Twitter use for two reasons: first, because a relevant part of the electorate is offline, which reinforces the significance of direct contact between voters and 
candidates; and second, because it is enough for city council candidates to meet the preferences of only a part of the electorate in order to get elected, which can cause some candidates to orient their campaign toward public spaces, such as neighborhoods. However, when candidates running for reelection adopted Twitter as part of their ecampaigns, they posted more tweets and gained more social media followers, and utilized this tool as a means to broadcast their political platforms and promote their campaign events. We also found that the political party to which councilors belong had minimal influence on the success of their campaigns. With the exception of small leftwing parties - those traditionally more interested in ideological debates, according to Singer (2000) - we found almost no evidence of candidates' parties influencing candidates' use of digital tools.

The following section presents a short literature review on social media and elections, and our three main questions. Next, we explain our methodology and empirical analysis, focusing on the importance of Twitter to the Fortaleza city councilors' campaign strategies (numbers of posts, followers and how many other users the councilors followed). We also study the contents of candidates' messages during the last week of the electoral race. Last, we present our findings, wherein we reveal that there was no direct relationship between electoral success and the heavy use of Twitter by the candidates.

\section{Review of the literature and main questions}

Studies on digital democracy over the last decade have focused on various research agendas. There are investigations on the improvement of administrative routines and services through e-government experiences (FOUNTAIN, 2009; HENMAN, 2013; PEREIRA et al., 2012), the transparency of representatives' political activities (FRICK, 2008; MARGETTS, 2011), and analyses concerning participatory tools sponsored by state institutions (MARQUES, 2010; MENDONÇA and AMARAL, 2014; SÆBØ et al., 2011; WRIGHT and STREET, 2007).

In particular, the topic of how the internet can be utilized as an outreach tool to voters is of particular interest to Brazilian political science researchers. Different works have examined at different levels how Brazilian candidates have used social media and other tools, like websites, during elections. Some articles also discuss variances in the way candidates have campaigned online during the last few years as new digital tools have 
emerged (AGGIO, 2010; CERVI and MASSUCHIN, 2011; GOMES et al., 2009; MARQUES and SAMPAIO, 2011). This study focuses on how Twitter-one of the SNSs ${ }^{1}$ - has been employed as part of political actors' communication strategies in election times.

After previous research recognized that members of legislative houses are constantly seeking reelection and will employ all tools available to assure their success (MAYHEW, 1974), the interest in the literature (the American case in particular) about the use of SNSs in election campaigns has grown (EVANS et al., 2014; WILLIAMS and GULATI, 2009).

Different scholars suggest that Twitter fosters a democratic communication, as it allows for on-the-ground reporting, provides opportunities for political conversations between representatives and their media staff and constituents, and influences both political journalism and independent political commentary (BOYD et al., 2010; BRUNS and BURGESS, 2011; LARSSON and MOE, 2011; LASSEN and BROWN, 2011; SMALL, 2011).

As we know that the usage of communication resources is only one factor that defines the performance of political agents, it is important to explore the main forms of use in electoral campaigns. Therefore, following what Sommerville (2009) explains below, a candidate's political strategy must be tailored to the candidate's intended audience.

Neighbourliness therefore seems to represent a first step towards a deeper level of involvement than the payment of respect to strangers: in becoming neighbours, people cease to be strangers to one another. This involves a stronger form of solidarity than that associated with civility, though it is more limited in scope. It leads to communitarian (sociability networks as 'in-groups') as opposed to cosmopolitan perspectives (based on notions of generalised interdependence)(SOMMERVILLE, 2009, p. 144).

Regarding Brazilian local elections, Ames (2001) affirms that:

Candidates' career trajectories constrain their campaign strategies and vote patterns. "Local" candidates - former mayors or city council members should always be plentiful. Except for those whose careers are rooted in large metropolitan areas, local candidates naturally develop concentrated distributions, because their name recognition decreases with the distance from their local job (AMES, 2001, p. 81).

1 According to Boyd and Ellison (2007, p. 02), SNSs are: "... Web-based services that allow individuals to (01) construct a public or semi-public profile within a bounded system, (02) articulate a list of other users with whom they share a connection, and (03) view and traverse their list of connections and those made by others within the system".

(2016) $10(3) \quad$ a $0005-5 / 35$


According to Carey and Shugart's (1995) model, candidates (mainly in local elections featured by a political system that fosters competition even among fellow party members) seek to strengthen their attributes (personal reputation) to distinguish themselves from other candidates. Other researchers investigated, more precisely, how the electoral system influences local elections' outcomes (GROFMAN, 2005; SANTOS, 2006).

Considering this previous research, if in a close election candidates tend to adopt media tools to increase their margin of votes (DRUCKMAN et al., 2009; WILLIAMS and GULATI, 2010), we asked what is the importance of digital media to candidates when a significant part of the candidates' constituency is offline or lives in a neighborhood where people meet each other regularly. Although Fortaleza has a population of over 2,5 million people according to the 2010 census (IBGE, 2012), the methods of connecting with voters are different in proportional elections, and this could influence the degree of adoption and the significance of digital media in the candidates' campaigns.

This study examines three main questions extracted from the literature on eelections. The first question refers to the influence of sociability on the ways the internet is used in local campaigns ${ }^{2}$. We examine whether the intimacy between voters and candidates continues to be important in proportional local elections at the very moment of voting decision, due to the prevalence of traditional mechanisms of persuasion (like family history or friendship relations) (HEREDIA et al., 2002; PALMEIRA, 2009).

The second question refers to the use of digital communication in reelection strategies. We examine whether candidates running for reelection adopt the intensive use of tweets as a campaign strategy and whether this tool is used to promote their ideas and campaign events. The third question refers to the relationship between party membership and the use of digital tools. We explore whether the councilors' respective political parties have any influence on the way candidates campaign.

In order to investigate these questions, this study focuses on how Twitter was employed by city council candidates in the 2012 electoral campaign in the Brazilian city of Fortaleza. In proportional elections, candidates do not need to reach the majority of votes to get elected. This means they can target their campaign to a specific audience or

\footnotetext{
2 For more details on local politics in Brazil, two references can be useful: Abers (2001) and
} Avritzer (2009). 
neighborhood, what could make sociability an important aspect to the election. We analyze the case of city councilors who ran for reelection and had registered official profiles on Twitter.

In 2012, Fortaleza had nearly 2.5 million inhabitants (IBGE, 2012). The total amount of voters registered in this municipality is more than 1.6 million (TSE, 2012). Data published by the United Nations reveals that Fortaleza is among the most unequal cities in the world regarding income, with a Gini coefficient above 0.6 (UN Habitat, 2010). This inequality is reflected in the ease of access to digital communication technologies. In Ceará, the Brazilian state where Fortaleza is located, only $12.5 \%$ of inhabitants have an internet connection available in their home (IPEA, 2012). Such factors offer an opportunity to investigate how communitarian sociability (closeness and direct interaction between voters and candidates) and mass sociability (mediated by diverse communications platforms, including digital media) are associated with attracting votes to candidates.

Fortaleza's City Council had 43 vacant seats in the 2012 elections. Thirty-three city councilors were running for reelection, but only 25 of them had a Twitter account. The research corpus comprises 27 Twitter accounts, after two candidates registered two more profiles in addition to the profiles they had already registered. There is another peculiarity which justifies the case study about Fortaleza; the number of parties with representatives on the city council. Twenty-two parties held seats during the 2009-2012 legislature ${ }^{3}$.

3 The following parties had, at least, one councilor on Fortaleza's City Council during the last legislature: PCdoB - Partido Comunista do Brasil (Communist Party of Brazil); PTN - Partido do Trabalho Nacional (National Labor Party); PSOL - Partido do Socialismo e Liberdade (Socialism and Freedom Party); PT - Partido dos Trabalhadores (Workers' Party); PMDB - Partido do Movimento Democrático Brasileiro (Party of the Brazilian Democratic Movement); PSDB Partido Social Democrata Brasileiro (Party of the Brazilian Social Democracy); PRB - Partido Republicano Brasileiro (Brazilian Republican Party); PT do B - Partido Trabalhista do Brasil (Labor Party of Brazil); PSB - Partido Socialista Brasileiro (Brazilian Socialist Party); PDT Partido Democrata Trabalhista (Democratic Labor Party); PTC - Partido Trabalhista Cristão (Christian Labor Party); PV - Partido Verde (Green Party); PHS - Partido Humanista da Solidariedade (Humanist Party of Solidarity); PTB - Partido Trabalhista Brasileiro (Brazilian Labor Party); PRP - Partido Republicano Progressista (Progressive Republican Party); PPS Partido Popular Socialista (Socialist Popular Party); PMN - Partido da Mobilização Nacional (National Mobilization Party); PR - Partido Republicano (Republican Party); PSL - Partido Social Liberal (Liberal Social Party); PP - Partido Progressista (Progressive Party); DEM - Democratas (Democrats). 
Moreover, the case of Fortaleza's city councilors' reelection campaigns was chosen for the following reasons: according to the Brazilian legislation, instead of competing for the votes of the majority of the whole constituency, it is sufficient for city council contenders to secure the votes of only a small part of the constituency. Therefore, a candidate who claims to defend the interests of a trade union or a neighborhood can orient their campaign toward those audiences. As we are dealing with a context marked by both communitarian and mass sociability, the Fortaleza case allows us to consider an approach that is uncommon in Brazilian studies on internet and elections.

Last, concerning the justification of why researching one city would be of interest to the current literature, it is important to highlight that we do share some of the reasons presented by Robert Dahl (1961) when he studied the case of New Haven, Connecticut in his classic "Who Governs?". First, just as New Haven is considered by Dahl (1961) as a typical American municipality, we argue that Fortaleza has multiple similarities with large cities in Brazil (especially when compared to other Brazilian states' capitals) which allows us to extend some of our findings to different contexts in the country. Second, similar to what Dahl (1961) said regarding the New Haven case, Fortaleza has some particular features (such as social inequalities and low rates of internet connection) that makes it a relevant example to discuss the limits of general findings common in Brazilian studies on e-democracy. Third, analyzing only one case allows us to explore it more carefully, exploring some details that would not be considered if other large cities were part of the sample. Again, this is in line with Dahl's argument (1961) that dealing with several aspects of New Haven was essential, since "Many problems that are almost unyielding over a larger area can be relatively easily disposed of on this smaller canvas"(DAHL, 1961, pp. V-VI). When we limit our research to a single city, we can work with different angles regarding Twitter use in a local context.

\section{Methodology}

This investigation first selected the Fortaleza city councilors who had registered Twitter accounts in the 2009-2012 legislature. In order to examine how important Twitter was to city council candidates' campaign strategy and reelection, we used a quantitative approach to observe (01) the tweets per week rate, (02) the number of followers and (03) the number of profiles followed by each city councilor. 
Table 01 presents all the city councilors that compose the sample for this study, as well their parties Twitter URLs and the day they created their accounts on the SNS.

Table 01. Fortaleza's city councilors on Twitter (June, 2012)

\begin{tabular}{|c|c|c|c|}
\hline Candidate's name & Party & Twitter URL & $\begin{array}{l}\text { Twitter account } \\
\text { created on }\end{array}$ \\
\hline Eliana Gomes & PCdoB & https://twitter.com/elianagpcdob & $05 / 27 / 2009$ \\
\hline Antônio Henrique & PTN & https://twitter.com/ver_henrique & $06 / 16 / 2009$ \\
\hline João Alfredo & PSOL & https://twitter.com/joaoalfredopsol & $07 / 30 / 2009$ \\
\hline Guilherme Sampaio & $\mathrm{PT}$ & https://twitter.com/verguilherme & $08 / 18 / 2009$ \\
\hline Vitor Valim & PMDB & https://twitter.com/vitorvalim & $08 / 19 / 2009$ \\
\hline Ronivaldo Maia & PT & https://twitter.com/ronivaldomaia & $08 / 31 / 2009$ \\
\hline Carlos Dutra & PSDB & https://twitter.com/cmfcarlosdutra & 09/12/2009 \\
\hline Gelson Ferraz & PRB & https://twitter.com/gelsonferraz & 09/18/2009 \\
\hline Leonelzinho Alencar & PTdoB & https://twitter.com/leonelzim70111 & $09 / 18 / 2009$ \\
\hline Salmito Filho (1)* & PSB & https://twitter.com/salmitofilho & $09 / 23 / 2009$ \\
\hline Plácido Filho & PDT & https://twitter.com/placido_filho & $01 / 13 / 2010$ \\
\hline Acrísio Sena & $\mathrm{PT}$ & https://twitter.com/acrisiosena & $25 / 02 / 2010$ \\
\hline Elpídio Nogueira & PSB & https://twitter.com/enmoreira & $04 / 24 / 2010$ \\
\hline $\begin{array}{ll}\text { Gerôncio } & \text { Coelho } \\
\text { (Alternate) } & \end{array}$ & PTdoB & https://twitter.com/geronciocoelho & $05 / 22 / 2010$ \\
\hline Walter Cavalcante & PMDB & https://twitter.com/waltervereador & $07 / 25 / 2010$ \\
\hline $\begin{array}{ll}\text { Toinha } & \text { Rocha } \\
\text { (Alternate) } & \end{array}$ & PSOL & https://twitter.com/toinharochapsol & $08 / 02 / 2010$ \\
\hline Salmito Filho $(2)^{*}$ & PSB & https://twitter.com/salmito 40500 & $08 / 18 / 2010$ \\
\hline Dr. Ciro & PTC & https://twitter.com/drcirovereador & $09 / 24 / 2010$ \\
\hline Iraguassú Teixeira & PDT & https://twitter.com/iraguassu & $03 / 10 / 2011$ \\
\hline Adail Júnior & $\mathrm{PV}$ & https://twitter.com/vereador_adail & $04 / 26 / 2011$ \\
\hline $\begin{array}{l}\text { Alípio } \quad \text { Rodrigues } \\
(1)^{*}\end{array}$ & PTN & https://twitter.com/AlipioRodrigues & $07 / 20 / 2011$ \\
\hline Irmão Léo & PHS & https://twitter.com/irmao_leo & 09/08/2011 \\
\hline Paulo Gomes & PMDB & https://twitter.com/\#!/paulogomes15555 & $10 / 03 / 2011$ \\
\hline Magaly Marques & PMDB & https://twitter.com/magalymarques1 & $10 / 04 / 2011$ \\
\hline $\begin{array}{l}\text { Alípio Rodrigues } \\
(2)^{*}\end{array}$ & PTN & https://twitter.com/\#!/alpiorod & $10 / 25 / 2011$ \\
\hline Valdeck Vasconcelos & PTB & https://twitter.com/vereadorvaldeck & $04 / 07 / 2012$ \\
\hline $\begin{array}{ll}\text { Eron } & \text { Moreira } \\
\text { (Alternate) } & \end{array}$ & PV & https://twitter.com/eronmoreirapv & Closed his account \\
\hline
\end{tabular}

Source: Twitter

Note: $\left({ }^{*}\right)$ Candidates registered two profiles on Twitter: Salmito (01) and Salmito (02); Alípio Rodrigues (01) and Alípio Rodrigues (02). 
The data are publicly available on Twitter. Between July 2012 and November 2012, the authors gathered information every week to quantify the number of tweets published by the candidates, how many followers the candidates respectively gained, and the number of users being followed back by the city councilors.

Second, the method to analyze the content of the tweets allowed us to examine 1,852 tweets pulled from the Twitter timelines of 16 representatives who tweeted during the last electoral week of the 2012 campaign (between October 01 and October $07)^{4}$.

The 'corpus' of this part of the analysis comprises the same 27 Twitter accounts from Table 01. However, the period considered for examination is now reduced. Between July 06 and November 08, city councilors campaigning for reelection posted 15,675 tweets, and it would be impossible to scrutinize all of them. Therefore, the authors chose to analyze the tweets from the last week of the electoral campaign - from October 01 to October 07 . However, only 16 city councilors tweeted between October 01 and 07 , which possibly indicates the limited importance of Twitter to candidates in Fortaleza. Our sample consists of the content of 1,852 tweets, which represents approximately $11 \%$ of all posts.

Other authors have conducted content analyses to explore how Twitter is used by political actors. Small (2011), for example, provides an interesting content analysis on the role of political hashtags in Canada, shedding light on the fact that Twitter facilitates sharing real-time information. Adams and McCorkindale (2013) examined the Twitter accounts of the 2012 American presidential candidates, focusing on how engaged and transparent they were when interacting with their followers. However, there is little scholarship on the political aspects of Twitter regarding local elections. This paper seeks to fill in this gap by classifying all 1,852 tweets in the following categories, as defined by MARQUES et al. (2011).

01. Promotion of ideas: Tweets emphasizing political proposals, documents and campaign promises. This category also encompasses messages that invite users to visit the list of proposals available on the candidates' websites.

\footnotetext{
${ }^{4}$ Other articles, especially Golbech et al. (2010) and Glassman et al. (2010) deal with the content of tweets published by representatives during mandates. Nevertheless, Brazilian articles specifically examining the case of city councilors in a large city are exceptions.
} 
Example: "Our slogan during my term was...Courage to struggle...we propose the democratization of decent housing in our city. Take a look at our proposals at http://t.co/Or6MdzC0\#Elia na65123"

Source: Fortaleza City Council candidate Eliana Gomes (@eliana65123) - October 05, 2012.

02. Negative campaign: Tweets by candidates criticizing other ones who were running for city council or for Fortaleza's City Hall. This kind of post may also include criticisms of opinion poll institutes or about the press.

Example: "Moroni's [a candidate who was running for mayor] bodyguards just attacked our fellow citizens at Ferreira Square. This is the 'democracy' he says he wants to defend".

Source: Fortaleza City Council candidate AcrísioSena (@acrisiosena) - October 06, 2012.

03. Mobilization and engagement: Emphasis on tweets that invite voters to help the candidate gain votes or to encourage citizens to publicly support a candidate.

Example: "Good morning everyone. This is the last week of our campaign. We need you to go to the streets in order to renovate [our politics]. \#Weareall50".

Source: Fortaleza City Council candidate Toinha Rocha (@toinharochapsol) - October 01, 2012.

04. Promoting campaign events: Tweets that highlight public events organized to support a candidate. The main objective is to inform voters about campaign events, but not necessarily call for a campaign action.

Example: "Coming soon: Jean Wyllys attends our Diversity Meeting this Wednesday (03) http://renatoroseno.com.br/jean-wyllys-participa-do-encontro-com-a-diversidadenesta-quarta-3/...You are all invited".

Source: Fortaleza City Council candidate João Alfredo (@joalfredo50_050) - October 03, 2012.

05. Tweets unrelated to politics or with no specific classification: Posts about issues or personalities that are not necessarily linked to the political race. There were a small amount of tweets without specific content (for example, the tweet was simply a link without any accompanying text to explain the tweet) or the tweet was incomprehensible. Tweets that did not fit one of the categories referred to above were also put in this category. 
Example: "History is in mourning - Eric Hobsbawn is dead. He is the author of The Age of Revolution, The Age of Empire, The Age of Capital and The Age of Extremes - analysis about XX Century".

Source: Fortaleza City Council candidate AcrísioSena (@acrisiosena) - October 01, 2012.

In order to increase the reliability of the classification for each tweet, in case of disagreements regarding the categorization of a tweet, we discussed possible arguments until a consensus was reached about the classification. Even so, the authors acknowledge the risks and benefits of a qualitative analysis in this case.

During April 2013 we also conducted nine face-to-face polls with several of the councilors (or their media staff) whose Twitter accounts were studied. We asked them how they managed their Twitter account, their personal reasons for using Twitter, the importance of the digital tool in their campaigns, and if their parties had encouraged them to maintain accounts on social media networks ${ }^{5}$.

Tweeting, following, and following back: can twitter usage be associated with electoral success?

This section explores whether Twitter was a successful tool for Fortaleza's city councilors' reelection strategies. The data analyzed in this section encompasses the period between July 06 (the day in which electoral campaigns officially start, according to Brazilian law) and November 08, 2012 (a Thursday, two weeks after municipal elections took place in Brazilian cities). On a weekly basis, the number of followers, accounts followed and tweets of each candidate were updated by the authors.

The next two charts summarize how Fortaleza's city councilors used Twitter. Chart 01 corresponds to the tweets per week rate of each city councilor, and Chart 02 shows a comparison between the total number of tweets posted by parliamentarians during the first week of July and during the first week of November.

\footnotetext{
5 We spoke with Acrísio Sena; Alípio Rodrigues; Alana Fernandes (who worked for Carlos Dutra); Danilo Amaral (who worked for Gelson Ferraz); João Alfredo; Leonelzinho Alencar; Ronivaldo Maia and his media consultant, Benedito Teixeira, and Toinha Rocha.
} 
Chart 01. Tweets per week rate

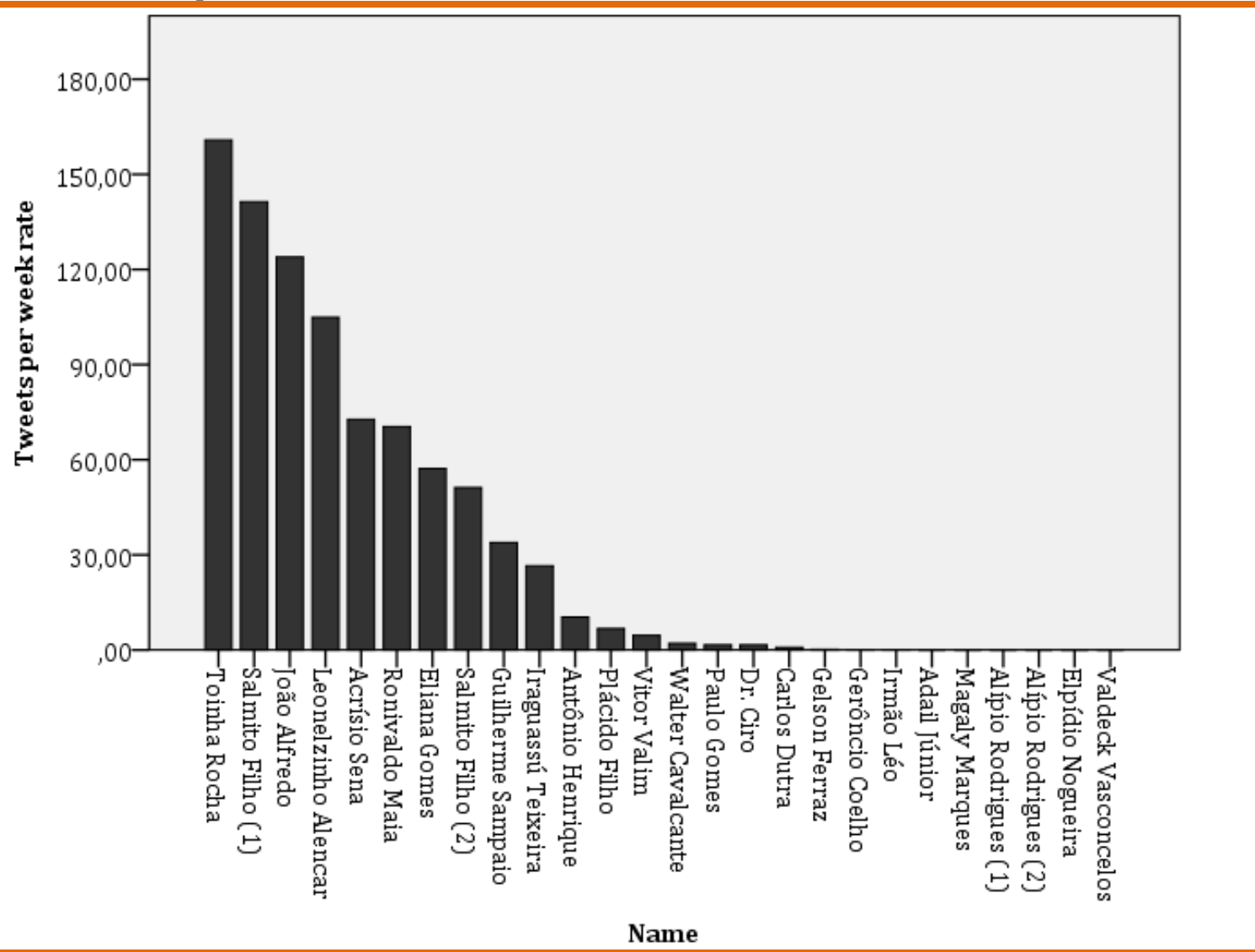

Source: Twitter.

Chart 02. Total number of tweets (between July 2012 and November 2012)

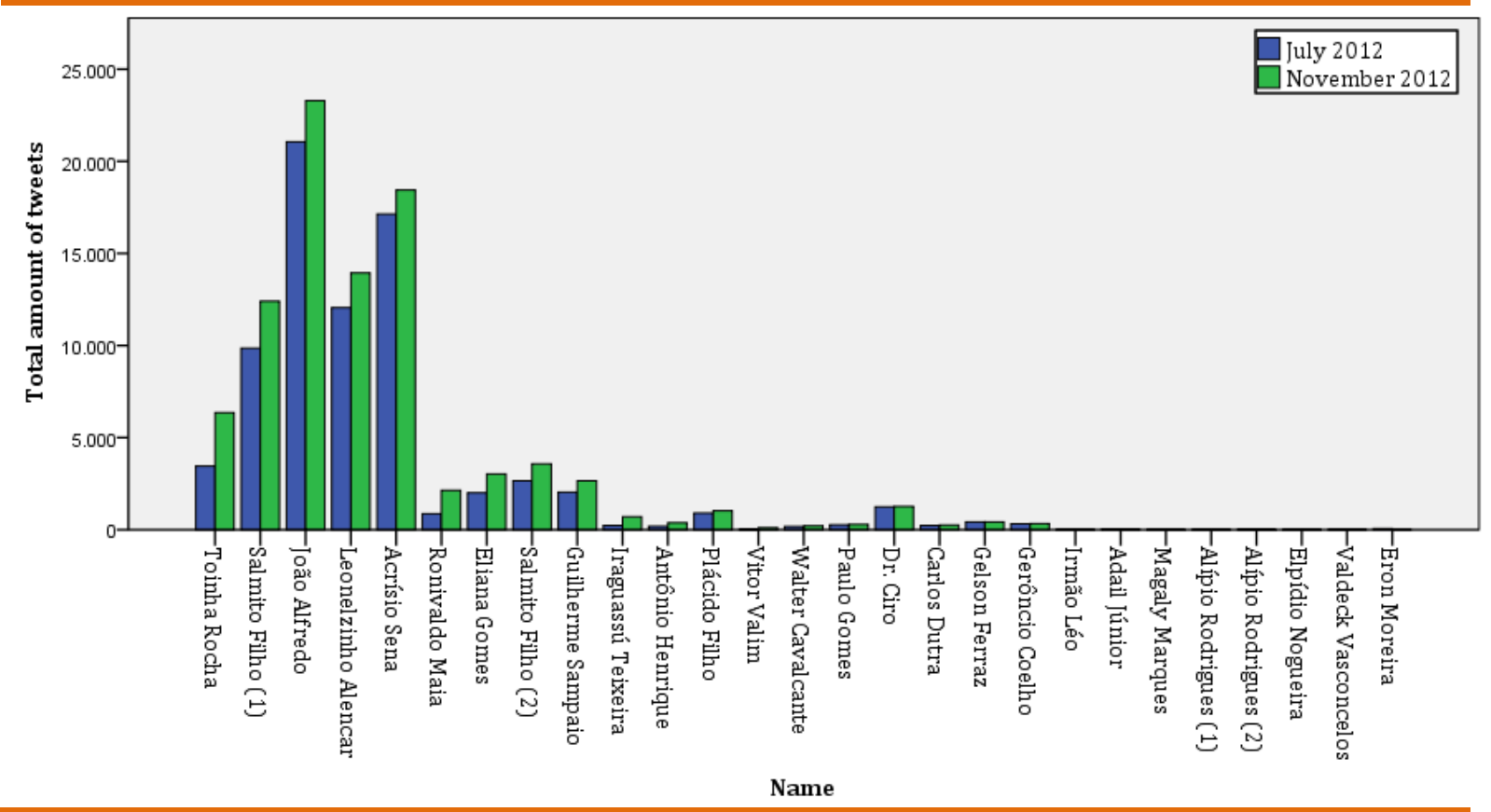

Source: Twitter. 
João Alfredo, Acrísio Sena, Leonelzinho Alencar, Salmito Filho (01) and Toinha Rocha are, respectively, the candidates who published the most tweets if we consider the absolute data in November 2012. They rank the highest in terms of post activity if we take into account the tweets per week rate. As expected, there is a natural correlation among total number of tweets and tweets per week rate.

The number of tweets posted between July and November shows that some of the city councilors clearly used the tool with electoral purposes. Acrísio Sena (7.6\%), João Alfredo (10.6\%) and Leonelzinho Alencar (15.7\%) showed an impressive growth in their posts during the electoral period; they posted more than 10,000 tweets each when data collection began. At least for these candidates, communication through Twitter was part of their efforts to build their public images.

However, our data also shows that a sudden substantial increase in the percentage of published tweets does not necessarily indicate a frequent use of the tool by candidates. Vitor Valim, for instance, registered his profile in August 2009. Until the first week of July, he had posted only 20 messages. However, during the first week of November, his personal account had a total of 103 posts, an increase of $415 \%$ during the period analyzed. Similarly, Iraguassú Teixeira and Ronivaldo Maia increased their tweet numbers $206.5 \%$ and $145.1 \%$, respectively. In spite of that, it is possible to say that, in these cases, the candidates' use of Twitter was sparse. Most likely, their goal was simply to be registered on this SNS. Even after creating an official profile, six city councilors did not use Twitter during the period examined.

The next two charts show the number of followers of each representative, as well as the new followers per week rate 6 .

\footnotetext{
${ }^{6}$ It is possible that not all users' followers are following a profile because the user is interested in the profile. There are services that sell followers on Twitter. See <http://bit.ly/PAI5xF>. Accessed on February 04, 2013.
} 
Chart 03. New followers per week rate

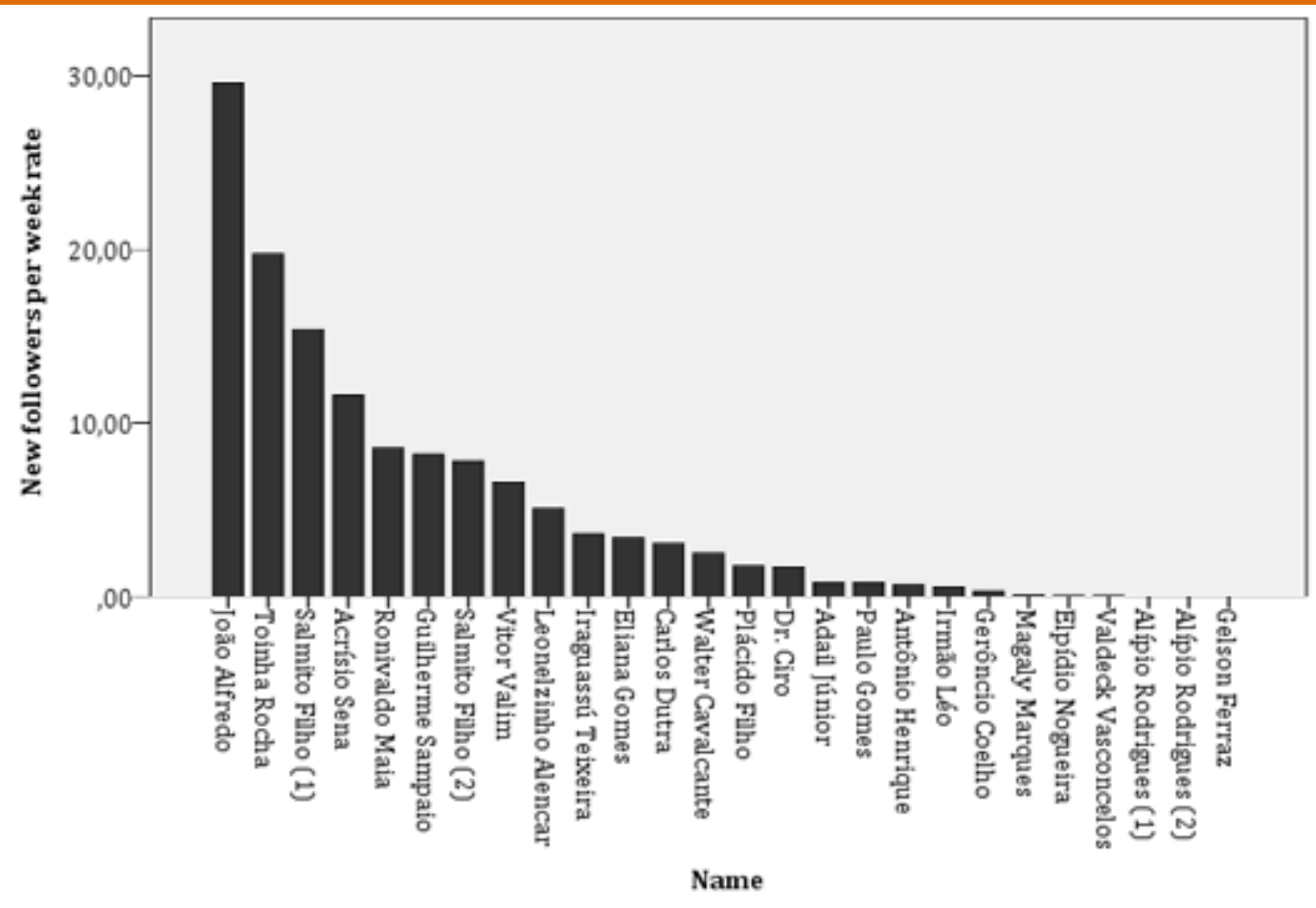

Source: Twitter.

Chart 04. Total amount of followers (July 2012 and November 2012)

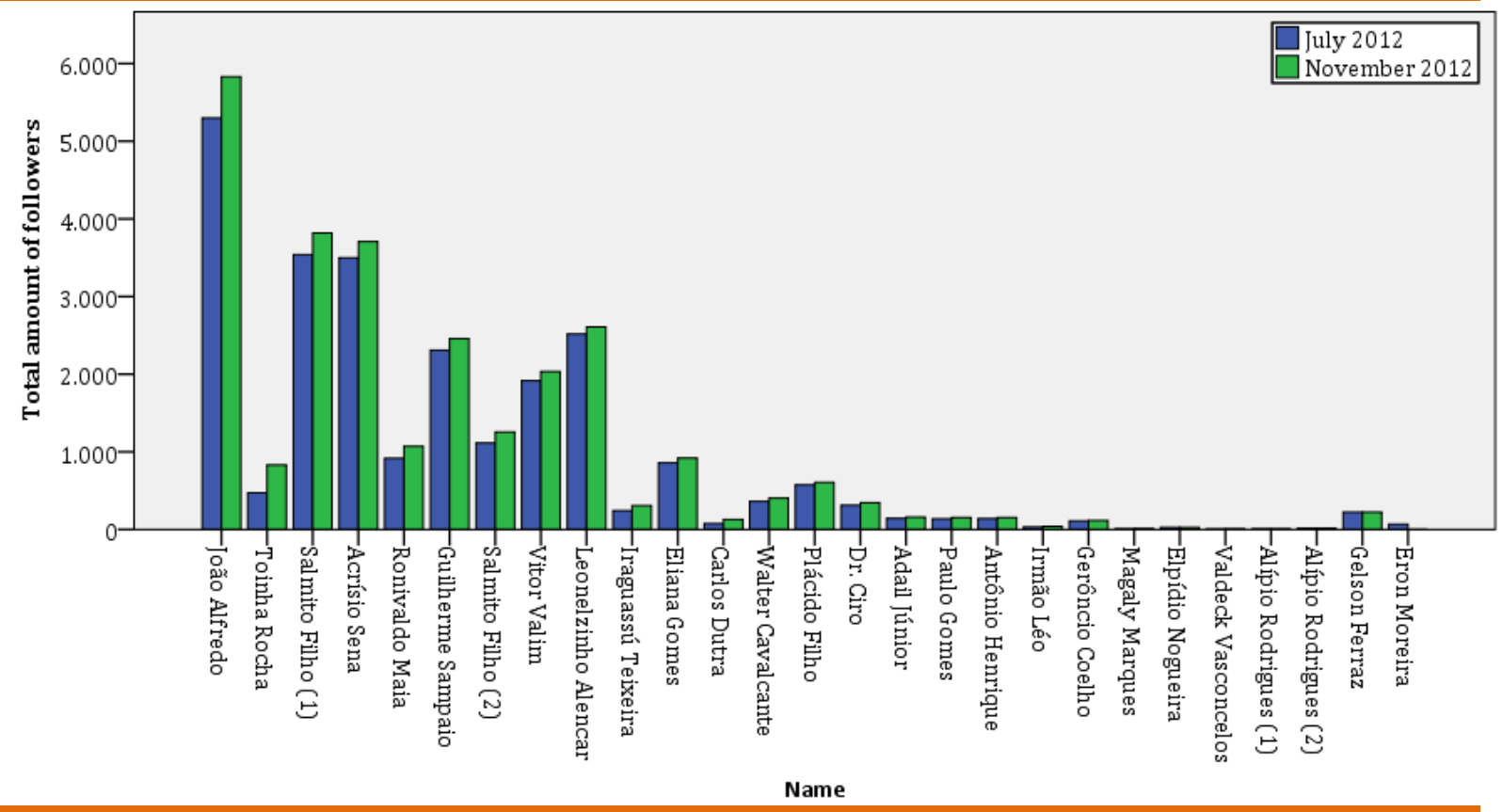

Source: Twitter.

In absolute numbers, the data indicate that the most-followed candidates were João Alfredo, Salmito Filho(01), Acrísio Sena, Leonelzinho Alencar and Guilherme Sampaio. Toinha Rocha increased her total amount of followers more than $75 \%$ if we 
compare the lapse between July 2012 and November 2012 and the period between August 2010 (when she registered her Twitter account) and June 2012.

Carlos Dutra (73.3\%), Irmão Léo (32.3\%) and Iraguassú Teixeira (26.3\%) significantly increased their total amount of followers from July to November 2012. However, if we consider only the absolute values, their progress is less impressive when compared to those candidates who used the tool more often.

Moreover, the numbers indicate that 11 city councilors amassed less than one new follower per week. This means that few citizens were interested in keeping up with these candidates' digital campaigns. Indeed, we can say that these candidates likely did not make any effort to attract new users, or maybe a relevant part of the candidates' target audiences are offline. As expected, there is a relevant relationship between not using Twitter and attracting a lower amount of new followers.

The following charts present information concerning users that candidates chose to follow. This is an indicator of how open these politicians are to listen to other users on Twitter.

Chart 05. New followings per week rate

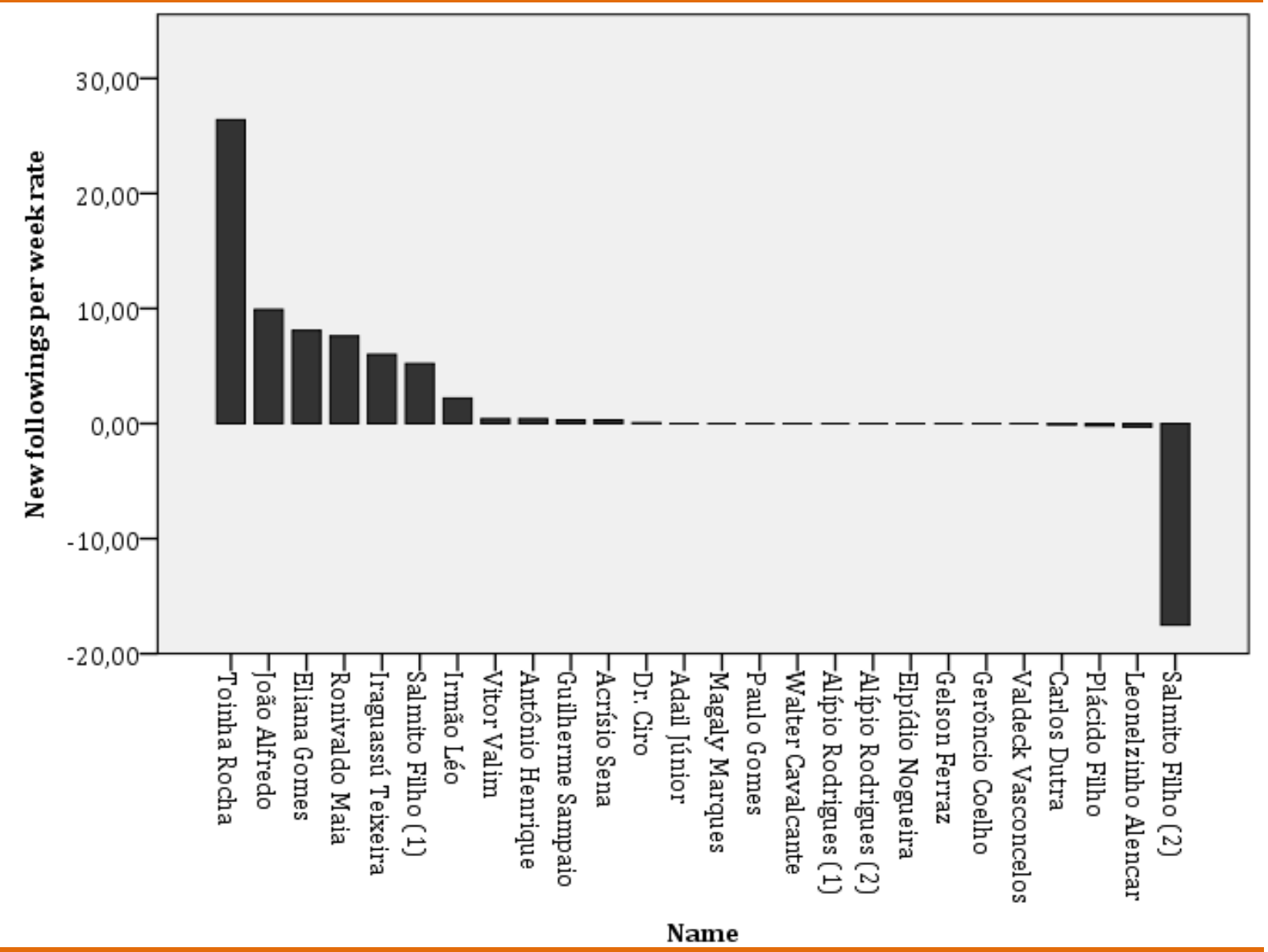

Source: Twitter 
Chart 06. Total amount of users being followed (July and November 2012)

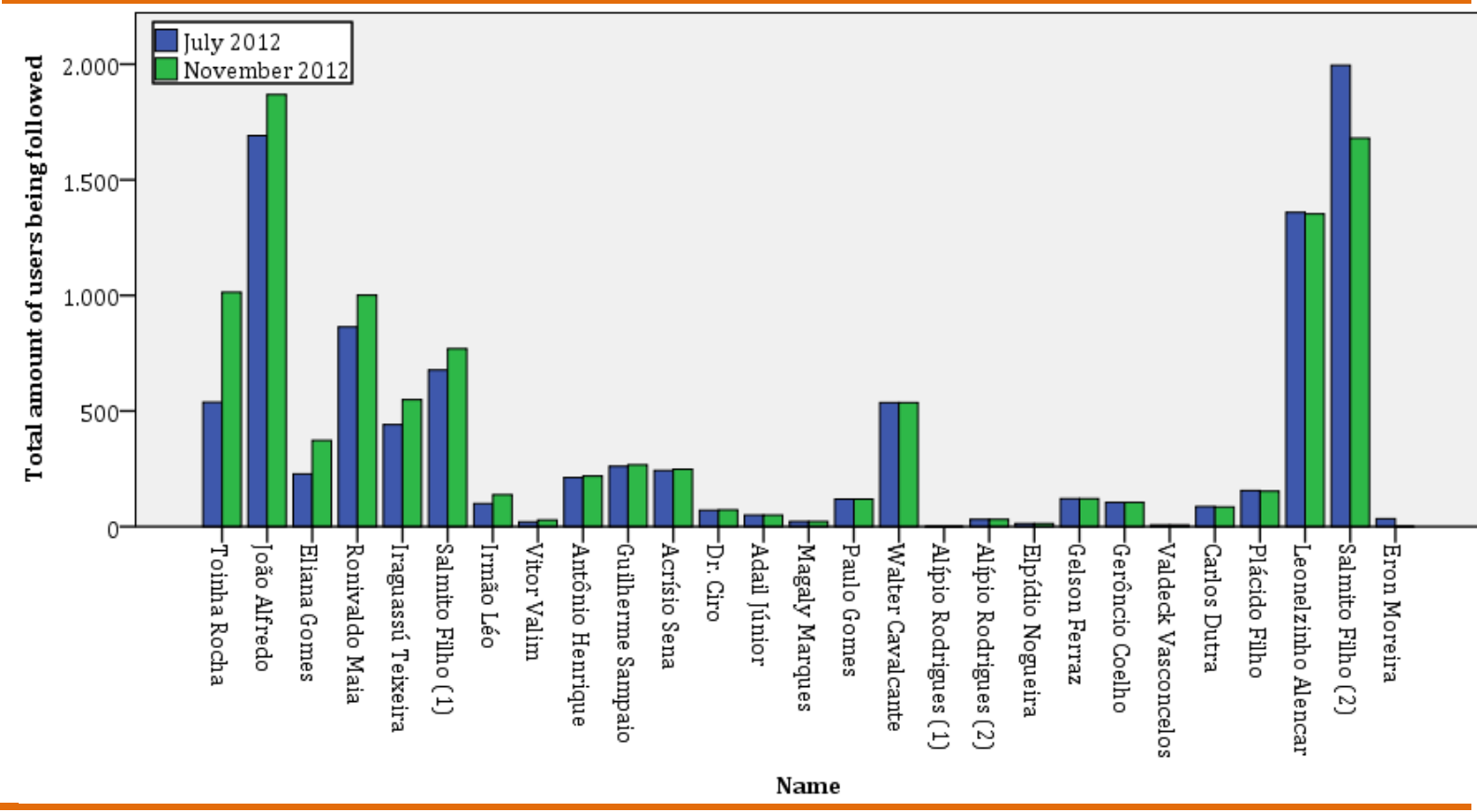

Source: Twitter.

The numbers disclose that João Alfredo, Salmito Filho(02), Leonelzinho Alencar, Toinha Rocha and Ronivaldo Maia are the candidates who were most likely to follow other users. Toinha Rocha, once more, showed an impressive growth in the number of other users she started to follow if we consider specifically the electoral period (88.5\%). Salmito Filho (02) faces a paradoxical situation: on one hand, he is one of the mostfollowed candidates; on the other, he stopped following other users (indeed, in his case there is a decrease of $15.8 \%$ ). Filho also had a second profile, registered as Salmito Filho (01), which increased the amount of users being followed by him during the campaign.

Another relevant finding is that 19 city council candidates followed less than one new user per week (10 of them did not follow any user during the elections and four candidates unfollowed users more than followed new ones). In other words, many city councilors did not show any concern about receiving updates on what journalists, supporters, or even common citizens had to say. To a large group of councilors, Twitter served mainly as a tool to publish information and their opinions, and not as a tool to encourage interaction.

To sum up, we found out that nearly 33\% of all Fortaleza's city councilors serving in the 2009-2012 legislature did not have a Twitter account during July 2012 (14 
out of $41^{7}$ ). This means that, even with the widespread use of digital tools, those representatives did not consider it important to have their voice on Twitter, and a significant part of those who had accounts did not choose to update them.

Of the 27 city councilors registered on Twitter in July 2012, 24 ran for reelection. If we include Toinha Rocha, as she was serving as councilor since early 2012, we have then one more councilor running for reelection. Of these 25 parliamentarians, 18 had posted less than 1,000 tweets between the dates they respectively registered on Twitter and July 2012. Four months later, in November 2012, 16 of the 25 city councilors with a Twitter account still had less than 1,000 tweets. Therefore, for most of the Fortaleza city councilors, Twitter was a tool with little or no relevance to their campaigns.

Chart 07. Reelected top-rated city councilors that used Twitter (\% of valid votes)

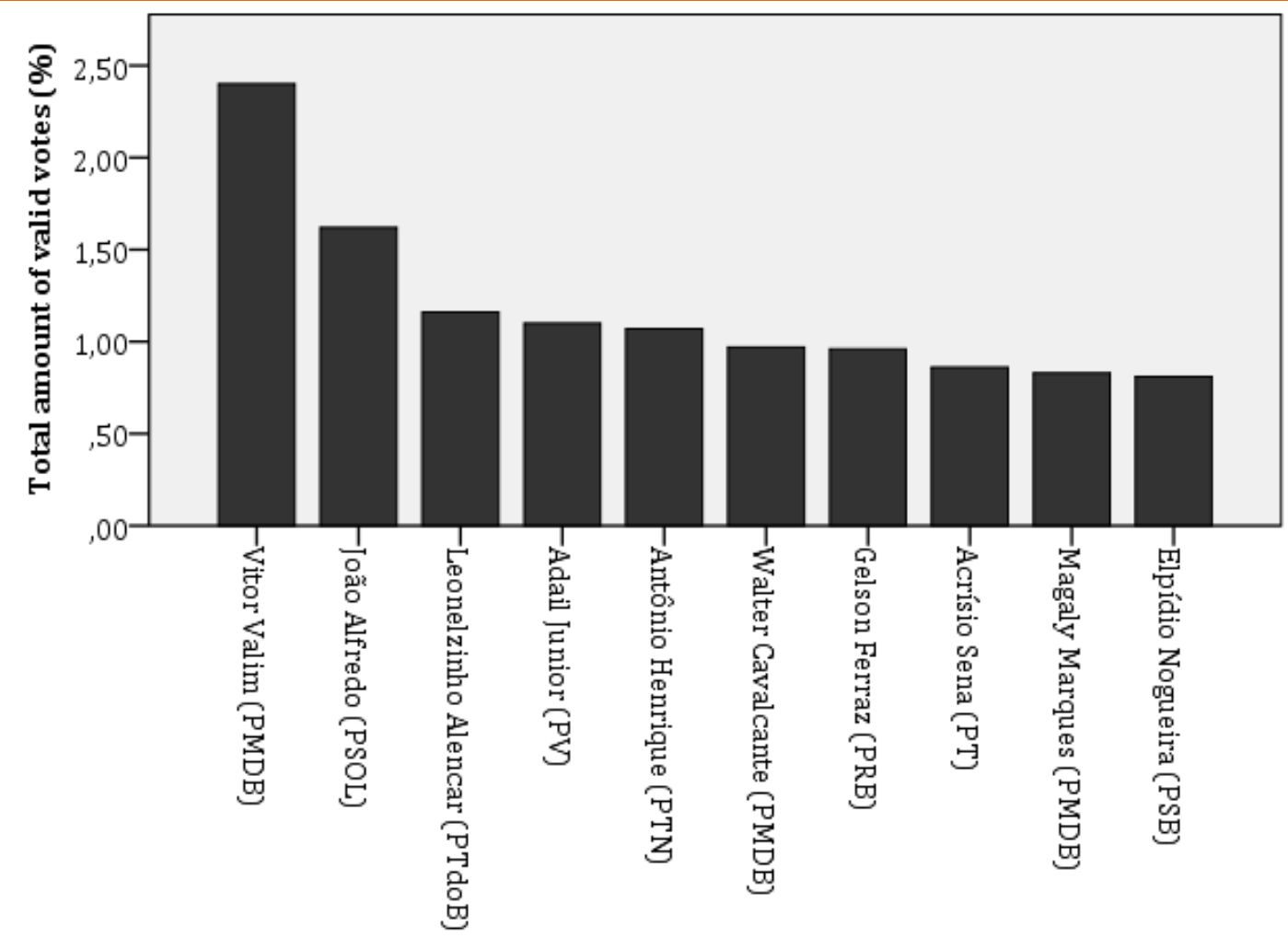

Name

Source: Twitter.

We then analyzed if Twitter use was associated with electoral success. The finding that Twitter was only of secondary importance to the majority of the candidates'

${ }^{7}$ Fortaleza City Council had 41 seats until 2012. In 2012, two more seats were added. 
success is highlighted by the fact that five of the 10 city councilors who received the most votes (Adail Junior, Walter Cavalcante, Gelson Ferraz, Magaly Marques and Elpídio Nogueira) were not among those who had the best rates in our study regarding the number of (a) tweets, (b) new followers or (c) following new users.

The data above shows that Twitter is not a necessary condition for getting elected, at least in proportional elections. Instead, the target audience determines whether and how digital tools are used.

The fact that incumbents have few followers indicates that sociability still happens, in a large part, outside SNSs. These data confirm, at least partially, our hypothesis about the importance of communitarian sociability in local proportional elections.

Nevertheless, using Twitter frequently can favor candidates. Considering the 10 city councilors with the higher tweets per week rate, only Eliana Gomes was not reelected. The same goes on with those who most followed other users. Regarding the top 10 candidates who gained the most new followers each week, it is important to note that all of them were reelected.

In local proportional elections, communitarian sociability can be more successful than mass sociability, since visiting voters' houses and talking to citizens on the streets can be more effective than being registered on every available social network site. In the context of a city like Fortaleza, where the internet is inaccessible to a large part of the constituency, the inability to reach the majority of citizens could possibly discourage the candidates' use of online tools, since a considerable number of constituents are not going to see messages published by candidates, and the resources spent to maintain profiles could generate better electoral results when focused on offline strategies instead.

\section{The "last" chance: What kind of contents are candidates tweeting about?}

This part of the analysis comprises the same 27 Twitter accounts held by city councilors in Fortaleza displayed in Table 01. Content analysis was adopted to examine the last week of the electoral campaign-from October 01, 2012 to October 07, 2012. Twitter messages were classified according to the following categories: 01) Promotion of Ideas; 02) Negative Campaign; 03) Mobilization and Engagement; 04) Promoting Campaign Events; and 05) Tweets Unrelated to Politics or with No Specific Classification. 
Chart 08 displays the distribution of tweets per day among candidates who used Twitter at least one time between October 01 and October 07. It indicates uniformity, except on October 05 , when 16 profiles collectively published 473 posts. The other days of the same week registered fewer tweets, reaching an average of 230 posts.

Chart 08. Total amount of tweets per day

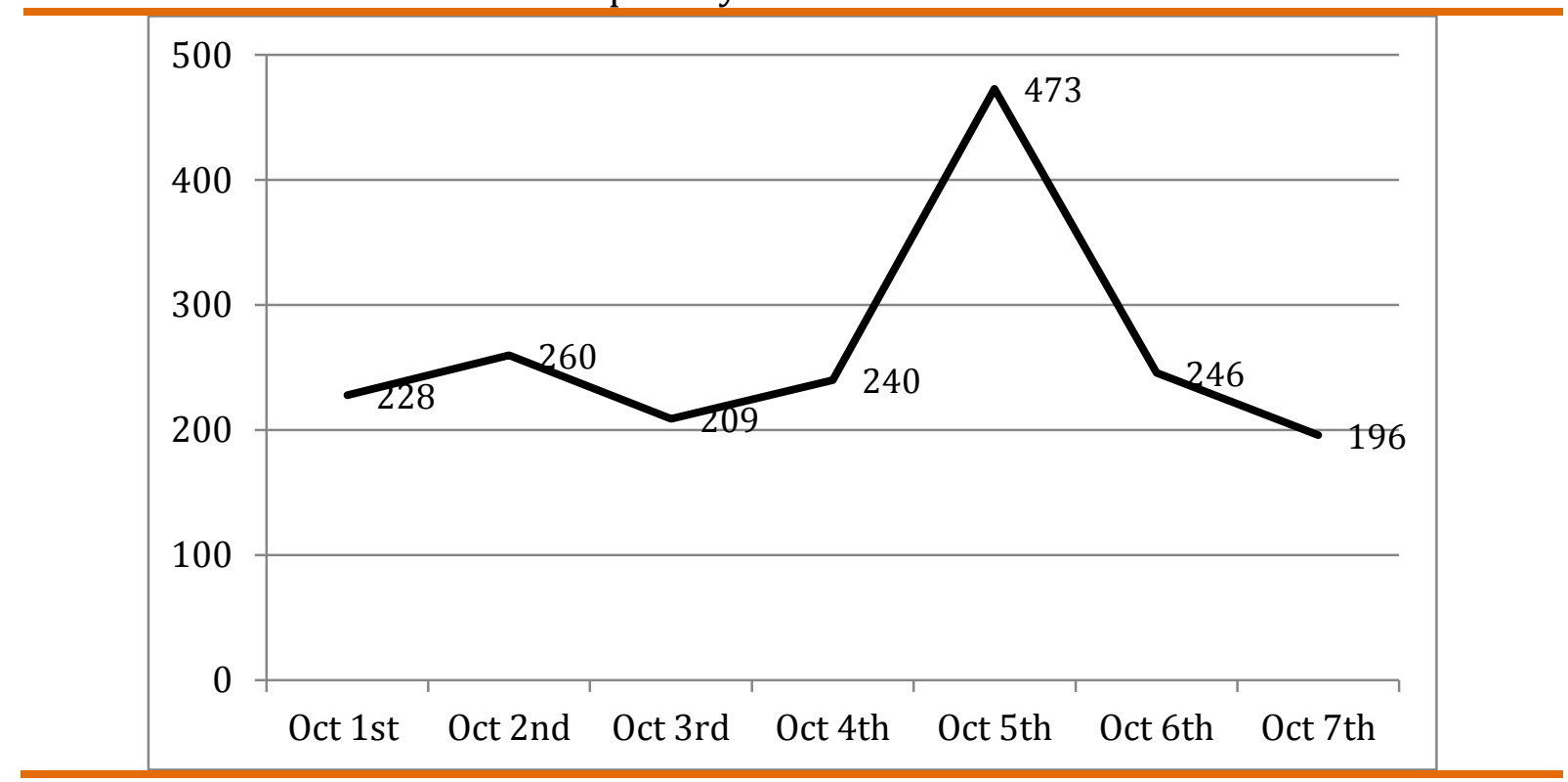

Source: Twitter.

Chart 09 indicates that Mobilization and Engagement (45.08\%) is the primary emphasis of the tweets. The quantity of messages posted in this category increased significantly in the elections' last four days. This reveals that as the election gets closer councilors tend to encourage voters to get engaged and show that candidates have support from other political agents. However, this does not necessarily apply to every candidate with profiles on Twitter, since some of them did not update their accounts during that week. 
Chart 09. Total amount of tweets per category and per day

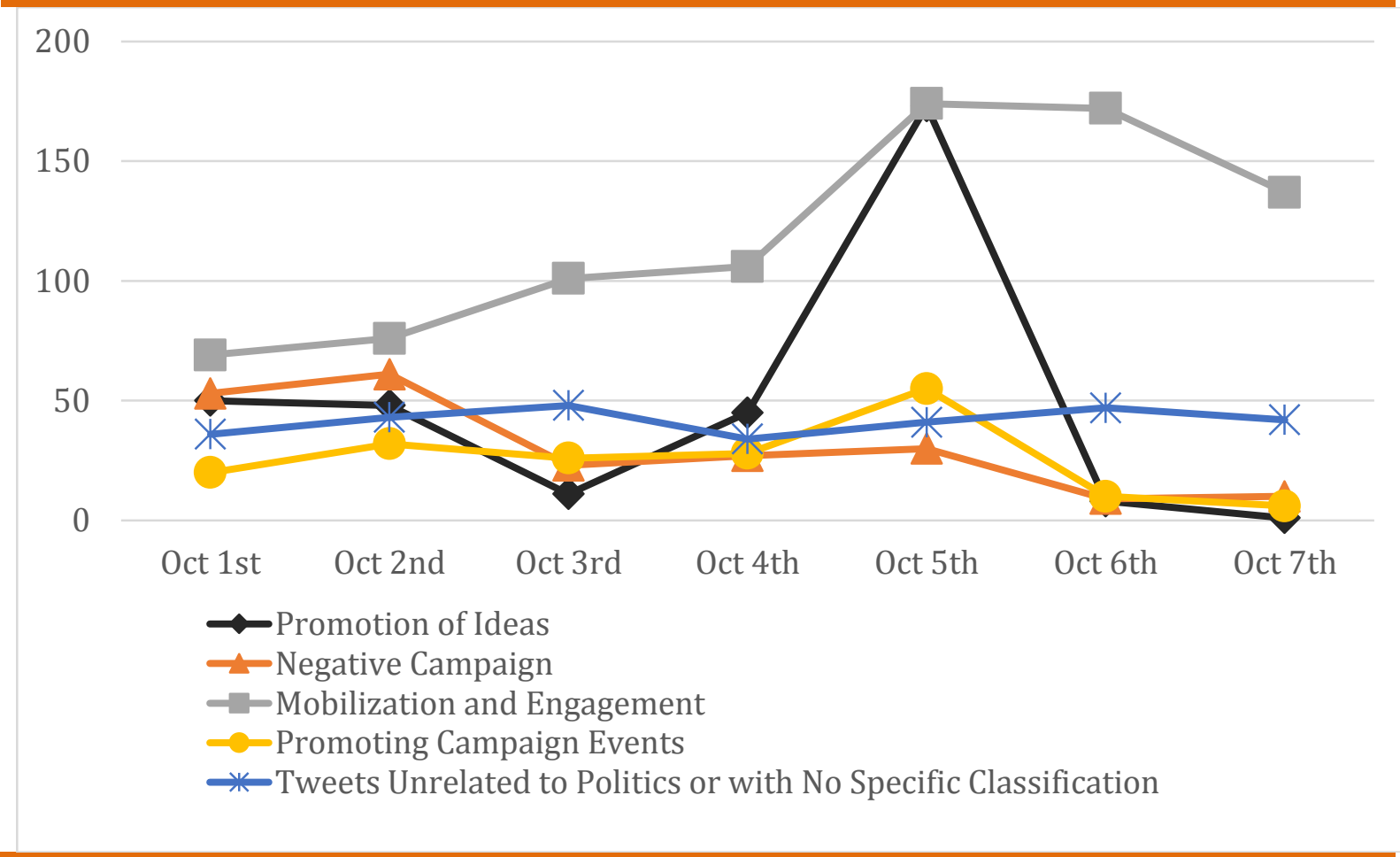

Source: Twitter.

Curiously, it is only on October 05 that the amount of tweets about Mobilization and Engagement $(n=174)$ is similar to the number of tweets regarding Promotion of Ideas $(n=173)$. This is likely a reinforcement of campaign promises in the few days before the election.

However, the interpretation seems misguided if we realize that precisely on October 06 and October 07 we see fewer tweets promoting ideas than in all the seven days examined. The same goes on with Promoting Events and Negative Campaign tweets: they decrease significantly in the last two days. Only Mobilization and Engagement messages and tweets Unrelated to Politics or with No Specific Classification kept their regularity.

Another possibility to explain the peak of tweeting on October 05 is the fact that this was the last day when, according to the Brazilian legislation, candidates could use traditional media for campaign purposes.

Our expectation was that councilors would keep a high tweet per day rate on the following days, but this did not happen. These data reinforce the idea that Twitter was not used as a strategic tool by most of the candidates in our sample. The rates of Twitter usage among the candidates remained the same even after the end of ads on TV and on the radio. The election day is the exact day with fewer tweets published in the period studied-in the last moments, it is crucial for city councilors to occupy the neighborhood streets and gain 
more votes, although Brazilian law forbids campaigns on the streets or on mass media during election day.

The second most-frequent category is Promotion of Ideas. However, we found that only $18.14 \%$ of all tweets belong in this category. The difference between Promotion of Ideas (18.14\%) and Mobilization and Engagement (45.08\%) was that candidates' primary goals were to achieve support for their candidacy, instead of defending an agenda or debating ideas.

Tweets unrelated to politics or with no specific classification reached $15.71 \%$ of the posts. It is important to notice the relevant quantity of tweets that simply presented a link (with no description) or messages with no context (comments about soccer games, for example). Nevertheless, almost $85 \%$ of all tweets concern campaign issues.

Negative Campaign tweets show one of most abrupt decreases over the days that encompass our sample. Candidates attack their rivals mainly in the beginning of the last week, and not in the end of it. Probably, the low index of Negative Campaign (only $11.5 \%$ of the messages) is due to the fact that councilors run for proportional offices. Thus, it is not easy to identify a direct competitor to be criticized, except when there is competition for voters in the same region of a city. Here we can offer more evidence about how the Brazilian electoral system also influence the low index of Negative Campaign as well. As Evans et al. (2014) argue, district elections tend to have a stronger negative campaign than those without clear divisions. Since there are no official district divisions in the Brazilian city councilors' elections, candidates tend to promote less negative campaigns.

Promoting Campaign Events is the less frequent kind of tweet (9.55\%). Even with a busy schedule in the last week of their campaigns (making visits to community associations, for instance), city council candidates showed little concerned about inviting voters to follow or to participate in political meetings.

The prevalence of Mobilization and Engagement messages may indicate an attempt to "control" interaction with other users (Stromer-Galley, 2000), as voters are invited to participate, but with clear limits. Users' roles seemed to be reduced to getting new votes and being persuaded to vote. Participating in the definition of political proposals is not a priority. However, there are some profiles that used the tool in a participatory fashion - even in electoral periods - like those examined by Marques et al. (2011).

To sum up, the data allows us to say that some candidates had a very high number of tweets and followers, but a significant part of them were not heavy Twitter users. 
Nevertheless, most tweets published in the last week of the race were related to political issues: tweets with no specific classification represent $15.7 \%$ of the total, while those categorized in one of the political typologies adopted in this study represent about $85 \%$ of all the content published.

Chart 10 indicates the distribution of tweets published by each candidate, according to our categories of classification, during the period observed in our study.

Chart 10. Distribution of tweets per city councilor and per category

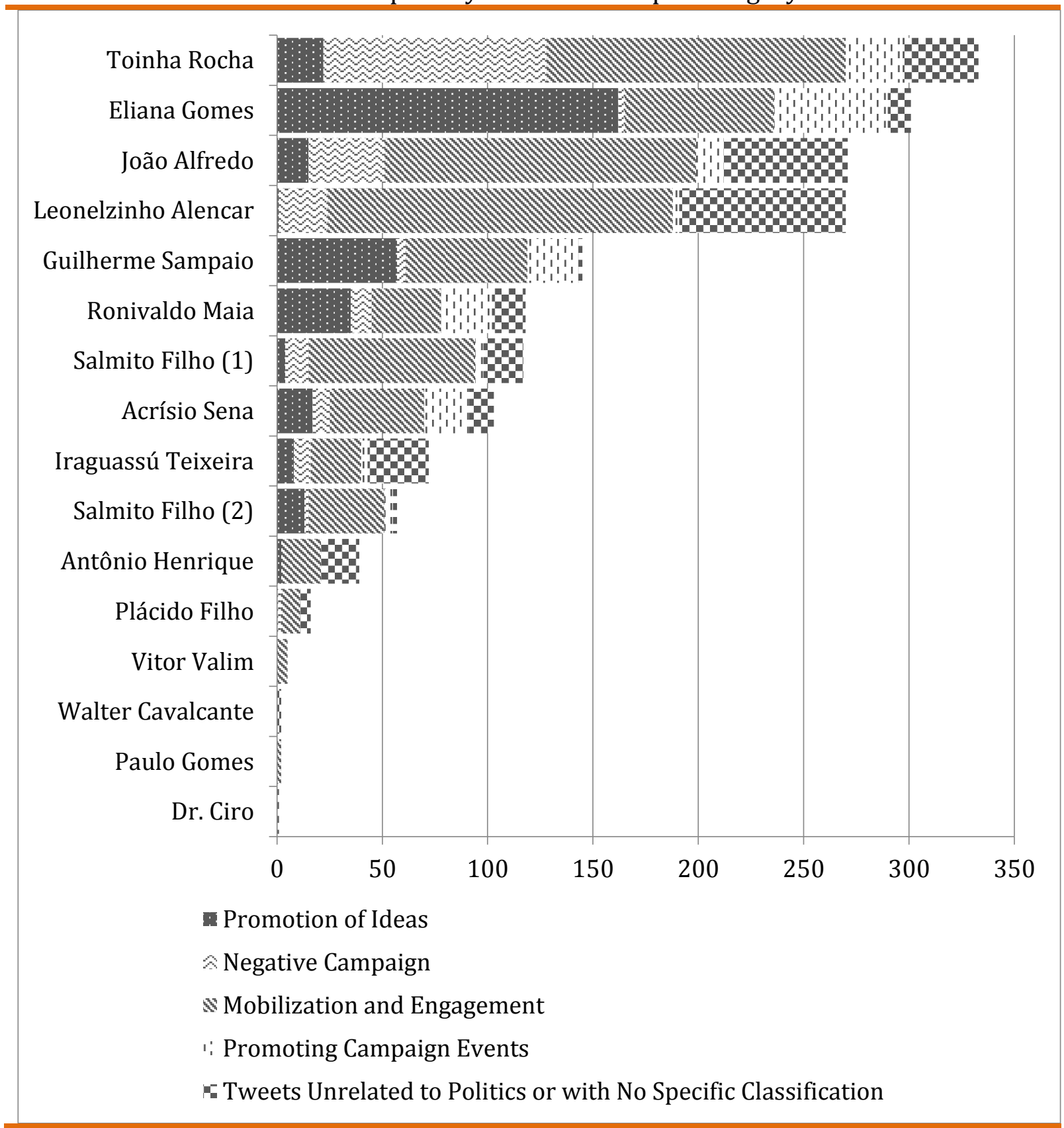

Source: Twitter. 
It is important to highlight that three city councilors (Toinha Rocha, Eliana Gomes and João Alfredo) accounted for $48.86 \%$ of the tweets posted by all the candidates in the week between October 01 and October 07.

Concerning the three PT councilors who ran for reelection-Guilherme Sampaio, Ronivaldo Maia and Acrísio Sena-we identified distinct patterns of Twitter usage. Sampaio and Maia are among the councilors who most promoted ideas, considerably more than Sena did. However, most of their tweets just reproduced the content posted by the PT candidate for mayorship, Elmano de Freitas. In Sena's case, he manages his own Twitter account in order to strengthen his campaign, (compared to Maia, whose staff manages his account ${ }^{8}$ ) which can explain why he tends to publish content that is often directly related to him. Lucas and Samuels (2011) argue that the only Brazilian party with some ideological coherence, and the one in which positions are clearly distinct from other parties, is PT (PSOL was not considered in the analysis). This could explain why councilors belonging to PT emphasize ideas in their tweets, and those ideas are often shared by other candidates of the party.

Toinha Rocha emphasized Mobilization and Engagement. However, tweets that focused on Negative Campaign were a special category for her: only Rocha accounted for $49.8 \%$ of all tweets placed on this category. The strong Negative Campaign made by the two candidates of PSOL (Socialism and Freedom Party) can be explained by the fact that this party is opposed to the current mayor of Fortaleza. As part of the city council minority, they have greater difficulty to make their ideas visible through TV advertisements, which pushes them to use digital tools. Lassen and Brown (2011) discovered similar findings in their study of the American case. According to their study, Republicans-who were in the minority in the American Congress at the time of the authors' study-were more active on Twitter than Democrats, as an "effort to circumvent the traditional media dominance of the majority party" (LASSEN and BROWN, 2011, p. 431). This finding is also reinforced by other investigations, like the one made by Aragón et al., 2012.

The amount of Negative Campaign $(n=106)$ and Mobilization and Engagement ( $n=142$ ) tweets by Rocha contradicts what she said in an interview, wherein she said

\footnotetext{
${ }^{8}$ Since it was not possible to interview Guilherme Sampaio or his staff, there is no way to know for certain who updates the councilor's account.
} 
that her main use of Twitter was dedicated to present ideas and promote debates with other users (ROCHA, 2013). However, during the analyzed period, Promoting Ideas represented only $6.6 \%$ of her tweets. Evans et al. (2014) argue that third parties tend to publish more attacks against rivals. PSOL, the party to which Rocha (2013) belongs, can be considered a third party in Brazil and traditionally criticizes other candidates (as can be seen in ASSUNÇÃO et al., 2015), which could explain the reason Negative Campaign is so frequent in her tweets.

When we compared how councilors who belong to the same political party behave on Twitter, we found out that there is little pattern between them. Excepting PSOL, the usage of Twitter varies from party to party. For example, while João Alfredo and Toinha Rocha (PSOL) have a similar tweets per week rate and followers and users followed by them, Salmito Filho(01) is a heavy user on his personal profile while Elpídio Nogueira did not tweet or follow new users, and both of them belong to PSB. Two of PT's candidates, Acrísio Sena and Ronivaldo Maia, maintain a similar tweet per week rate, while the other PT candidate, Guilherme Sampaio, has a lower rate. Regarding PMDB, only Vitor Valim had a significant new followers per week rate, but none of the candidates tweet frequently. In PTN, Antônio Henrique has considerable tweets per week rate, while Alípio Rodrigues did not tweet during the entire campaign. To sum up, our data shows no relationship between published content and frequency of use of Twitter by candidates running from the same party, excepting small left-wing parties.

Moreover, our interviews offered interesting explanations as to why some candidates did not tweet during the last week of the election. Gelson Ferraz's campaign, for instance, prioritized Facebook. According to his media consultant, Danilo Amaral (2013), Facebook usage was more common among the voters they intended to reach. Alípio Rodrigues did not show any familiarity with Twitter during the interview. This could explain why he posted no tweets during the electoral period, despite having two profiles registered on Twitter.

In the end, our interviews with city councilors revealed that using Twitter seems to be more of an individual decision, and what makes a political agent keep or discontinue his participation on Twitter is his own sense of convenience. The finding shows there is no encouragement by parties to their councilors regarding the usage of digital tools. This situation is the opposite of the findings of Lassen and Brown (2011) regarding the candidates running for the United States House of Representatives. In that 
context, they noticed that the adoption of Twitter was encouraged by the Republican Party and their leaders, who were the minority in the House during the analyzed period. In the case analyzed here, not even the parties that opposed the current mayor of Fortaleza had a clear strategy about Twitter use, which reveals that city councilors run their campaigns without partisan guidance.

\section{Conclusions}

The recent literature on the effects of the internet on elections has revealed some of the most significant cases of how SNSs are being used to help citizens choose representatives. However, we lack a more careful examination of local cases in which candidates do not need to gain the majority of voters, but only a part of them. One of the goals of this article was to contribute to this task by analyzing the use of Twitter by Fortaleza's city councilors who ran for reelection in October 2012. Our focus was to understand if and how sociability influences the ways the internet is used in local campaigns.

Our study show that communitarian sociability (in which physical contact and day-to-day intimacy helps to explain political support) was not replaced by mass sociability (by using TV ads) as a result of the emergence of the internet tools on elections, at least in proportional local elections taking place in large cities where poverty hinders large constituencies to become internet users. Our analysis indicates that the electorally-relevant sociability still takes place outside SNSs.

Although some candidates running for reelection in city councils display a high amount of tweets and followers and most of their tweets are related to political issues, most of the candidates did not reveal to be heavy internet users. Internet users did publish during the last campaign week though advertising their political agendas.

Finally, the party to which councilors belong to has little or no influence on their digital campaigns. The analysis shows no relationship between content and frequency use of Twitter by candidates running from the same party.

The fact that a large majority of Fortaleza's city councilors are modest regarding Twitter use indicates the importance they give to this tool: on one hand, even if the majority of Fortaleza's city councilors were registered on Twitter, they are not likely to regularly use this tool, and when they do, they are likely unwilling to dialogue with other users. Therefore, being online does not guarantee that politicians will adopt an 
interactive approach of communication tools. However, when the target audience is composed of internet heavy users, it is mandatory to have an updated and interactive profile (DRUCKMAN et al., 2009; MARQUES et al., 2014; ROCHA, 2013). Hence, the range and features of each constituency seems to determine how likely candidates will be to use digital tools in their campaigns. This finding is in line with Amman's (2010) conclusion that candidates tweet more depending on the demand they experience from their base of support.

One of our most important findings is that the scarce use of Twitter does not affect reelection in the case of the Fortaleza City Council, probably because the primary electors who most interest some candidates are not online. In local proportional elections, visiting voters' houses and talking to citizens on the streets seems to be more effective, and shows that communitarian sociability is still effective, meaning it happens, in a large part, outside SNSs.

Therefore, it seems that local elections' strategies could be different from those employed by candidates who are running for state or national offices, since the literature on e-campaigns does not reflect the fact that many citizens are more influenced by direct, personal contact. Another difference between other national and state campaigns is the fact that even in key moments of the campaign (such as the last week when candidates work even harder for votes) only a few councilors use Twitter. As the study of the contents of the tweets showed, even in the last week of the campaign, Twitter was not used as a strategic tool by most of the candidates in our sample.

In this sense, it is also useful to compare the Brazilian and the American cases regarding the role of political parties encouraging Twitter usage. Haber (2011) points out that partisan identification in the US is important because it reflects the disputes between Democrats and Republicans, the mainstream parties in the country. Since these parties have more resources (EVANS et al., 2014), candidates belonging to smaller parties tend to use Twitter more frequently, which the authors identified as an attempt to compensate for the lack of coverage the smaller parties receive in traditional media outlets.

However, our empirical study points toward three that can affect the candidates' usage of Twitter: multiparty contexts tend to reduce party loyalty; the fact that there is no district in a city that promotes competition between candidates of the same party for 
the same voter; parties offer little to no incentive for city council candidates to use digital communications tools.

The electoral scenario is one aspect to be carefully considered in future research dedicated to understand how sociability affects political campaigns on the internet: if one candidate is successfully using SNSs to attract voters by discussing his proposals, his competition will likely be more interested in learning how to use SNSs to keep up with the competition. However, other aspects must be considered, like the influence of the electoral system. These findings are similar to the American case, as stated by Lassen and Brown (2011).

Therefore, a wide range of other issues related to how candidates use Twitter deserve further research. For example, the effects of Twitter usage over different political cultures and institutional designs; the influence of elections times on boosting the candidates' number of followers; the role of political consultants and how they manage Twitter profiles during a campaign; how fake accounts have been used to attack opponents and promote negative campaigns; the findings that could emerge once Twitter and Facebook usage are compared; and the use of Twitter outside of electoral contexts. In the end, the various agendas we suggest are evidence that different variables have to be considered when we attempt to understand how and why politicians adopt digital technologies as part of their campaigns.

Revised by Lindsey Silva Submitted on June 17, 2015 Accepted on March 22, 2016

\section{References}

ABERS, Rebecca (2001), Inventing local democracy: Grassroots politics in Brazil. Boulder: Lynne Rienner. 269pp.

ADAMS, Adams and MCCORKINDALE, Tina (2013), Dialogue and transparency: a content analysis of how the 2012 presidential candidates used Twitter. Public Relations Review. Vol. 39, № 04, pp. 357-359.

AGGIO, Camilo (2010), Campanhas Online: o percurso de formação das questões, problemas e configurações a partir da literatura produzida entre 1992 e 2009. Opinião Pública. Vol. 16, № 02, pp. 426-445.

ALDÉ, Alessandra and MARQUES, Francisco Paulo Jamil (Eds.) (2015), Internet e Poder Local. Salvador: EDUFBA. 424pp.

(2016) 10 (3) $\quad$ e0005-28/35


AMARAL, Danilo. Interview with Camila Mont'Alverne. Fortaleza, 09 April, 2013.

AMMAN, Sky (2010), Why do they tweet? The use of twitter by U.S. Senate candidates in 2010. Social Science Research Network. Available at http://ssrn.com/abstract=1725477. Accessed on 17 April, 2016.

ARAGÓN, Pablo et al. (2012),Tweeting the campaign: evaluation of strategies performed by Spanish political parties on Twitter for the 2011 national elections. Policy and Internet. Vol. 05, № 02, pp. 183-206.

ASSUNÇÃO, A.; ALDÉ, A.; SANTOS, J. G. and FREIRE, F. (2015), Estratégias de campanha política on-line: Marcelo Freixo nas eleições para a prefeitura do Rio de Janeiro em 2012. In: Internet e Poder Local. Edited by ALDÉ, Alessandra and MARQUES, Francisco Paulo Jamil Salvador: EDUFBA. pp. 13-48.

AVRITZER, Leonardo (2009), Participatory institutions in democratic Brazil. Washington D.C.: Woodrow Wilson Center Press. 205pp.

BAQUERO, Marcelo (Ed.) (1997), Novos padrões de comportamento eleitoral: pragmatismo nas eleições municipais de 1996 em Porto Alegre. In: A lógica do processo eleitoral em tempos modernos: novas perspectivas de análise. Porto Alegre: Editora da Universidade. pp. 123-140.

BIMBER, Bruce and DAVIS, Richard (2003), Campaigning online: the internet in U.S. elections. New York: Oxford University Press. 240pp.

BORBA, Julian (2005), Cultura política, ideologia e comportamento eleitoral: alguns apontamentos teóricos sobre o caso brasileiro. Opinião Pública. Vol. 11, № 01, pp. 147-168.

BOYD, Danah and ELLISON, Nicole (2007), Social network sites: definitions, history, and scholarship. Journal of Computer-Mediated Communication. Vol. 13, № 01, pp. 210230.

BOYD, Danah; GOLDER, Scott and LOTAN, Gilad (2010), Tweet, tweet, retweet: conversational aspects of retweeting on Twitter. Proceedings of the 43rd Annual Hawaii International Conference on System Science. Available at http://www.danah.org/papers/TweetTweetRetweet.pdf. Accessed on 17 April, 2016.

BRAGA, Sergio; NICOLAS, Maria Alejandra and BECHER, André Roberto (2013), Clientelismo, internet e voto: personalismo e transferência de recursos nas campanhas online para vereador nas eleições de outubro de 2008 no Brasil. Opinião Pública. Vol. 19, № 01, pp. 168-197.

BRUNS, Axel and BURGESS, Jean (2011), \#ausvotes: how Twitter covered the 2010 Australian federal election. Communication, Politics and Culture. Vol. 44, № 02, pp. 37-56. 
CAREY, John M., and SHUGART, Matthew S. (1995). Incentives to cultivate a personal vote: A rank ordering of electoral formulas. Electoral Studies. Vol. 14, № 04, pp. 417439.

CARREIRÃO, Yan de Souza (2000), A decisão do voto nas eleições presidenciais no Brasil (1989 a 1998): a importância do voto por avaliação de desempenho. $P h D$ Dissertation. Universidade de São Paulo.

CASTRO, Mônica Mata Machado de (1997), O comportamento eleitoral no Brasil: diagnóstico e interpretações. Teoria e Sociedade. № 01, pp. 126-168.

CERVI, Emerson and MASSUCHIN, Michele G. (2011), 0 uso do twitter nas eleições de 2010: o microblog nas campanhas dos principais candidatos ao governo do Paraná. Contemporânea. Vol. 09, pp. 174-189.

CHAIA, Vera; MENEGUELLO, Rachel; AZEVEDO, Fernando and SCHMITT, Rogério (2002), São Paulo: embate partidário, mídia e comportamento eleitoral. In: Estratégia, mídia $e$ voto: a disputa eleitoral em 2000. Edited by SILVEIRA, Flávio Eduardo. Porto Alegre: EDIPUCRS. pp. 17-47.

COLEMAN, Stephen (Ed.) (2001), Elections in the age of the Internet: lessons from the US. London: Hansard Society. 67pp.

DAHL, Robert (1961), Who governs? Democracy and power in an American City. New Haven and London: Yale University Press. 355pp.

DRUCKMAN, James; KIFER, Martin J. and PARKINET, Michael (2009), The technological development of candidate web sites: how and why candidates use web innovations. In: Politicking online: the transformation of election campaign communications. Edited by PANAGOPOULOS, Costas. Piscataway: University Press, pp. 21-47.

ENLI, Gunn Sara and SKOGERBO, Eli (2013), Personalized campaigns in party-centred politics. Information, Communication and Society. Vol. 16, № 05, pp. 01-18.

EVANS, Heather K.; CORDOVA, Victoria and SIPOLE, Savannah (2014), Twitter style: an analysis of how house candidates used Twitter in their 2012 campaigns. Political Science and Politics. Vol. 47, № 02, pp. 454-462.

FIGUEIREDO, Marcus (1991), A decisão do voto democracia e racionalidade. Belo Horizonte: UFMG, 1991. 239pp.

FORTUNATI, L., Taipale, S. and Luca, F. (2013). What happened to body-to-body sociability? Social Science Research. Vol. 43, № 03, pp. 893-905.

FOUNTAIN, Jane E. (2009), Bureaucratic reform and e-government in the United States: an institutional perspective. In: The Routledge handbook of Internet politics. Edited by CHADWICK, Andrew and HOWARD, Philip N.. New York: Routledge. pp. 99-113. 
FRICK, Maria (2008), Translucent states: political mediation of e-transparency. International Journal of Electronic Government Research. Vol. 04, № 03, pp. 81-102.

GAMSON, William (1992),Talking politics. Cambridge: Cambridge University Press. 292pp.

GLASSMAN, Matthew; STRAUS, Jacob R. and SHOGAN, J. (2010), Social networking and constituent communications: member use of Twitter during a two-month period in the 111th Congress. Congressional Research Service. Available at http://www.fas.org/sgp/crs/misc/R41066.pdf. Accessed on April 17, 2016.

GOLBECK, Jennifer; GRIMES, Justin and ROGERS, Anthony. (2010), Twitter use by the U.S. Congress. Journal of the American Society for Information Science and Technology. Volume 61, № 08. pp. 1612-1621.

GOMES, Wilson (2004), Transformações da política na era da comunicação de massa. São Paulo: Paulus. 451pp.

GOMES, Wilson; FERNANDES, Breno; REIS, Lucas and SILVA, Tarcizio (2009), 'Politics 2.0': a campanha online de Barack Obama em 2008. Revista de Sociologia e Política. Vol. 17. № 34, pp. 29-45.

GROFMAN, Bernard (2005), Comparisons among electoral systems: distinguishing between localism and candidate-centered politics. Electoral Studies. Vol. 24, № 04, pp. 735-740.

HABER, Steven (2011), The 2010 U.S. Senate elections in 140 characters or less: an analysis of how candidates use Twitter as a campaign tool. Available at http://goo.gl/1hn3WQ. Accessed on April 17, 2016.

HACKER, Kenneth L. (Ed.) (2004), Presidential candidate images. Oxford: Rowman \& Littlefield Publishers. 256pp.

HENMAN, Paul (2013), Government and the Internet: evolving technologies, enduring research themes. In: The Oxford handbook of Internet studies. Edited by DUTTON, William. Oxford: Oxford University Press. pp. 283-306.

HEREDIA, Beatriz; TEIXEIRA, Carla and BARREIRA, Irlys (Eds.) (2002), Como se fazem eleições no Brasil. Rio de Janeiro: Relume Dumará. 274pp.

HOWARD, Phillip. N. (2005), Deep democracy, thin citizenship: the impact of digital media in political campaign strategy. The Annals of American Academy of Political and Social Science. Vol. 597, № 01, pp. 153-170.

HOWARD, Phillip. N. (2006), New media campaigns and the managed citizen. Cambridge: Cambridge University Press. 288pp.

IBGE (Instituto Brasileiro de Geografia e Estatística) (2012),Dados básicos. Available at http://bit.ly/11U1uNp. Accessed on April 17, 2016. 
IPEA (Instituto de Pesquisa Econômica Aplicada) (2012), Situação social nos estados Ceará. Série Situação Social. Brasília. Available at: http://www.ipea.gov.br/portal/images/stories/PDFs/situacao_social/120201_relat orio_situacaosocial_ce.pdf. Accessed on April 17, 2016.

JACKSON, Nigel and LILLEKER, Darren (2009), Interacting, representing or just informing: Web 2.0 and UK MP? Paper presented at 05th ECPR General Conference. 10-12 September 2009, Potsdam, Germany.

KARLSEN, Rune (2010), Fear of the political consultant: campaign professionals and new technology in Norwegian electoral politics. Party Politics. Vol. 16, № 02, pp. 193-214.

LARSSON, Anders Olof and MOE, Hallvard (2011), Studying political microblogging: Twitter users in the 2010 Swedish election campaign. New Media and Society. Available at http://nms.sagepub.com/content/early/2011/11/21/1461444811422 894.abstract. Accessed on April 17, 2016.

LASSEN, David and BROWN, Adam R. (2011), Twitter: the electoral connection? Social Science Computer Review. Vol. 29, № 04, pp. 419-436.

LUCAS, Kevin and SAMUELS, David (2011), A "coerência" ideológica do sistema partidário brasileiro, 1990-2009. In: O Congresso por ele mesmo: autopercepções da classe política brasileira. Edited by POWER, Timothy and ZUCCO JR., Cesar. Belo Horizonte: Editora UFMG, pp. 61-103.

MAIA, Rousiley (2011), Internet e esfera civil: limites e alcances da participação política. In: Internet e participação política no Brasil. Edited by MAIA, Rousiley; GOMES, Wilson and MARQUES, Francisco Paulo Jamil. Porto Alegre: Sulina. pp. 47-91.

MARGETTS, Helen (2011), The Internet and transparency. The Political Quarterly. Vol. 82, № 04 , pp. 518-521.

MARQUES, Francisco Paulo Jamil (2010), "Muro baixo, o povo pula": iniciativas institucionais de participação digital e seus desafios fundamentais. Opinião Pública. Vol. 16, pp. 117-142.

MARQUES, Francisco Paulo Jamil; SILVA, Fernando Wisse Oliveira and MATOS, Nina Ribeiro (2011), Estratégias de comunicação política online: uma análise do perfil de José Serra no Twitter. Contemporânea. Vol. 09, № 03, pp. 344-369.

MARQUES, Francisco Paulo Jamil and SAMPAIO, Rafael C. (2011), Internet e eleições 2010 no Brasil: rupturas e continuidades nos padrões mediáticos das campanhas políticas online. Galáxia. Vol. 22, pp. 208-221.

MARQUES, Francisco Paulo Jamil; SAMPAIO, Rafael Cardoso and AGGIO, Camilo (Eds.) (2013), Do clique à urna: internet, redes sociais e eleições no Brasil. Salvador, EDUFBA. 371pp. 
MARQUES, Francisco Paulo Jamil; AQUINO, Jakson and MIOLA, Edna (2014), Congressmen in the age of social network sites: Brazilian representatives and Twitter use. First Monday. Vol. 19, pp. 01-20.

MAYHEW, David R. (1974), Congress: the electoral connection. New Haven, CT: Yale University Press. 216pp.

MENDONÇA, Ricardo Fabrino and PEREIRA, Marcus (2012), Democracia digital e deliberação online: um estudo de caso sobre o VotenaWeb. Revista Latinoamericana de Opinión Pública. Vol. 02, pp. 109-158.

MENDONÇA, Ricardo Fabrino and AMARAL, Ernesto (2014), Deliberação online em consultas públicas? O caso da assembleia legislativa de Minas Gerais. Revista Sociologia Política. Vol. 22, № 49, pp. 177-203.

MIGUEL, Luis Felipe (2000), Um ponto cego nas teorias da democracia: os meios de comunicação, BIB - Revista de Informação Bibliográfica em Ciências Sociais. № 49, pp. 41-79.

MILLIKEN, Kara (2011), Media use in the 2012 Presidential campaign. Available at http://tinyurl.com/cyyy8yn. Accessed on April 17, 2016.

PALMEIRA, Moacir (2009), Eleição municipal, política e cidadania. In: Política ambígua. Edited by PALMEIRA, Moacir and HEREDIA, Beatriz. Rio de Janeiro: Relume-Dumará. pp. 125-137.

PAPACHARISSI, Z. (2012), A networked self: identity performance and sociability on social network sites. In: Frontiers in new media research. Edited by LEE, F. L.; LEUNG, L.; QIU, J., and CHU, D.. New York, NY: Routledge. pp. 207-221.

PREECE, J. (2000), Online communities: designing usability, supporting sociability. Chichester, UK: Wiley. 468pp.

PUTNAM, R. (2000), Bowling Alone. New York: Simon and Schuster. 541pp.

PEREIRA, Marcus Abílio; FRIEDRICH, Ernesto and MENEZES, Marcela (2012), Some determinants of the existence of government Websites in 853 municipalities in Minas Gerais, Brazil. Latin American Research Review. Vol. 47, pp. 155-174.

POPKIN, Samuel (1994), The reasoning voter. Chicago: University of Chicago Press. 332pp.

PRZEWORSKI, Adam; CHEIBUB, José Antônio and LIMONGI, Fernando (2003), Democracia e cultura: uma visão não culturalista. Lua Nova. Vol. 58, pp. 09-35.

ROCHA, Toinha. Interview with Camila Mont'Alverne. Fortaleza, April 09, 2013.

RODRIGUES, Alípio. Interview with Camila Mont'Alverne. Fortaleza, April 09, 2013.

(2016) 10 (3) a e005-33/35 
SAKURAI, Sergio Naruhiko and MENEZES FILHO, Naercio (2011), Opportunistic and partisan election cycles in Brazil: new evidence at the municipal level. Public Choice. Vol. 148, № 01-02, pp. 233-247.

SANTOS, André Marenco dos (2006), Regras eleitorais importam? Modelos de listas eleitorais e seus efeitos sobre a competição partidária e o desempenho institucional. Dados. Vol. 49, № 04, pp. 721-749.

SÆBØ, Øystein.; FLAK, Leif and SEIN, MaungK (2011), Understanding the dynamics in eparticipation initiatives: looking through the genre and stakeholder lenses, government information. Quarterly. Vol. 28, № 03, pp. 416-425.

SCHUDSON, Michael (1995), The power of news. Cambridge: Harvard University Press. 288pp.

SELLERS, Patrick (2010), Cycles of spin: strategic communication in the U.S. Congress. Cambridge: Cambridge University Press. 270pp.

SINGER, André (2000), Esquerda e direita no eleitorado Brasileiro. São Paulo: Editora USP. 208pp.

SKIDMORE, Thomas (Ed.) (1993), Television, politics, and the transition to democracy in Latin America. Washington: The Woodrow Wilson Center Press. 200pp.

SMALL, Tamara (2011),What the hashtag? A content analysis of Canadian politics on Twitter. Information, Communication and Society. Vol. 14, № 06, pp. 872-895.

SOMERVILLE, Peter. (2009) 'The feeling's mutual': respect as the basis for cooperative interaction. IN: MILLIE, A. (ed.). Securing respect: behavioural expectations and antisocial behaviour in the UK. Bristol: The Policy Press. p. 139-167.

STROMER-GALLEY, Jennifer (2000), Online interaction and why candidates avoid It. Journal of Communication. Vol. 50, № 04, pp. 111-132.

SWANSON, David and MANCINI, Paolo (1996), Politics, media and modern democracy: an international study of innovations in electoral campaign and their consequences. Westport, Connecticut: Praeger. 285pp.

TELLES, Helcimara; LOURENÇO, Luiz Cláudio and STORNI, Tiago Prata (2009), Partidos, campanhas e voto: como o eleitor decide nas eleições municipais. Sociedade $e$ Cultura. Vol. 12, № 01, pp. 91-116.

TRIBUNAL SUPERIOR ELEITORAL (2012), Estatísticas TSE. Available at http://www.tse.jus.br/eleicoes/estatisticas/estatisticas-eleicoes-2012. Accessed on April 17, 2016.

UN HABITAT (2010), Urbandivides: Unequalcities. Available at http://mirror.unhabitat.org/documents/SOWC10/R8.pdf. Accessed on April 17, 2016. 
WELLMAN, B. (2001), Physical place and cyberplace. The rise of personalized networking. International Journal of Urban and Regional Research. Vol. 25, № 02, pp. 227-252.

WILLIAMS, Christine B. and GULATI, Girish J. (2009), Social networks in political campaigns: Facebook and Congressional elections 2006, 2008. Paper presented at the Annual Meeting of the American Political Science Association, Canada.

WILLIAMS, Christine B. and GULATI, Girish (2010), Communicating with constituents in 140 characters or less: Twitter and the diffusion of technology innovation in the United States Congress. Social Science Research Network. Available at http://papers.ssrn.com/sol3/papers.cfm?abstract_id=1628247. Accessed on April 17, 2016.

WRIGHT, Scott and STREET, John (2007), Democracy, deliberation and design: the case of online discussion forums. New Media and Society. Vol. 09, № 05, pp. 849-869. 